WHC-SA-1402-FP

in.

\title{
Nuclear Electric Propulsion Development and Qualification Facilities
}

Prepared for the U.S. Department of Energy Assistant Secretary for Nuclear Energy

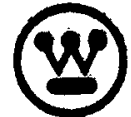
Westingthouse

Hanford Company Richland, Washington

Hanlord Operations and Engineering Contractor for the U.S. Department of Energy under Contract DE-AC06-87FL10980

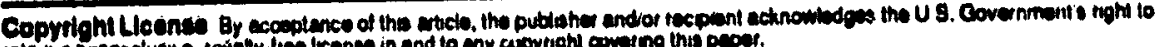

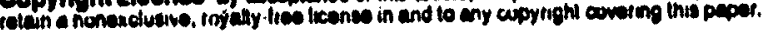




\section{LEOAL DISCLAIMER}

Th:s coport was preparod as an account of work sponso:ed by an agoncy of the Unitoo Statos Govornmont Noithor tho Unitoe Siatos Governmant nof any agoney thorool, nor any of inoif umployous, nor any of theip contractors. subcontractors of tho $r$ ampioyous makes any warranty. oxpross of impliod. of assumes any loga liability of responsibility to the accuracy. compiotonoss, or any third parly's use or the results of such se of any intormation, apparatus. product, or process c.sc osod or reprosents tha! its uso wouid not intringe orivalo'y ow nod tights Ra'urence harein to any spocilic commercia product. piocess. of service by lrade name. tracomara. manulacturor, or otherwiso, coes not necessarily cors: isle or moly its ondorsement, recommendation, or lavoring oy the Unitoc Slatos Government of any agoney thoreo? o its con!ractors or subcontractors The views and opinions o' authors expressed herein do not necessarily state or reflect those of ir.e United States Government of any agericy thoreot

Th.s report has been reproduced trom the best avalable copy

Printed in the Lnitod States of Americe

D!SC:M.2 CHP I 91 : 


\section{Nuclear Electric Propulsion Development and Qualification Facilities}

D. S. Dutt

Westinghouse Hantord Company

$K$. Thomassen

Lawrence Livermore National Laboratory

J. Sovey

NASA Lewis Research Center

M. Fontana

Cak Ridge National Laboratory

Date Published

November 1991

To Be Presented al

Ninth Symposium on Space

Nuclear Power Systems

Albuquerque, New Mexico

Jamuany 12-16, 1992

Prepared for the U.S. Department of Energy

Assistant Secretary for Nuclear Energy

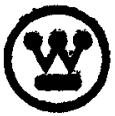

Mantord Oparations and Enoineerir. Contractor for the U.8. Department of Eneroy under Contrect DE-AC06-87RL10030

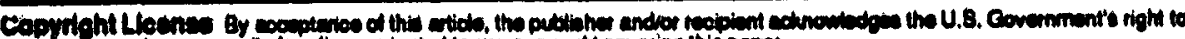

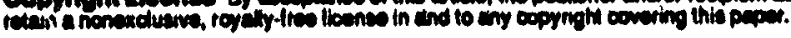




\title{
NUCLEAR ELECTRIC PROPULSION DEVELOPMENT AND QUALIFICATION FACILITIES
}

\author{
Dalo Dutt \\ Westinghouse Hanford Company \\ P. O. Box 1970 \\ Richlund, WA 99352 \\ (509) 376.9336 \\ Keith 'Thomassen \\ Luwrence Livermore National Laboratory \\ 7000 East Avenue \\ Livermore, CA 94550 \\ (415) 422.9815
}

\author{
Jim Sovoy \\ NASA Lowis Reseurch Center \\ 2100 Brookpark Roud \\ Clavelund, $\mathrm{OH} 44135$ \\ (216) 977.7454 \\ Mario Fontana \\ Oak Ridge National Laburatory \\ P. O. Box 2009 \\ Oak Ridge, TN 37831 \\ (615) $574-0273$
}

CAMERA READY MANUSCRIPT prepared for:

Ninth Symposium

on Space Nuclear Power Systems

Albuquerque, New Mexico

12.16 January 1992

initial submission:

final submission: $\quad 18$ November 1991

Author to whom correspondence should be sent: Dale Dutt 


\section{NUCLEAR ELECTRIC PROPULSION \\ DEVELOPMENT AND QUALIFICATION FACILITIES}

\author{
Dulo Duit \\ Westınghouss Hartiond Company \\ P. O. B $1 \times 1970$ \\ Richland, WA 99352 \\ (509) $376-9336$ \\ Keith Thomussen \\ Lawrence Livermore National Laboratory \\ 7000 Eust Avenue \\ Livermore, CA 94550 \\ (415) $422-9815$
}

\author{
Jim Sovey \\ NASA Lowis Reseurch Conter \\ 2100 Brovokpark Road \\ Clevolund. OH $4+135$ \\ (216) 977.7454 \\ Mario Fontana \\ Oak Ridyo Nutional Laboratory \\ P. O. Biox 2009 \\ Oak Ridge, TN 37831 \\ (615) $574-0273$
}

\section{Abstract}

This paper summarizes the findings of a Tri-Agency panel; consisting of members from the National Aeronautics and Space Administration (NASA), U.S. Department of Energy (DOE), and U.S. Department of Defense (DOD); charged with reviewing the status and availability of facilities to test components und subsystems for megawatt-class nuclear electric propulsion (NEP) systems. The facilities required to support development of NEP are available in NASA centers, DOE laboratories, and inclustry. However, several key facilities require significant and near-term modification in order to perform the testing required to meet a 2014 launch date. For the higher powered Mars cargo and piloted missions, the priority establishad for facility preparation is: (1 thruster developmental testing facility, (2 thruster lifetime testing facility, ( 3 dynamic energy conversion development and demonstration facility, and ( 4 advanced reactor testing facility (if required to demonstrate un advanced multiwatt power system). Facilities to support development of the power conditioning and heat rejection subsystems are available in industry, federal laboratories, and universities. In addition to the development facilities, a new preflight qualification and acceptance testing facility will be required to support the deployment of NEP systems for precursor, cargo, or piloted Mars missions. Because the deployment strategy for NEP involves early demonstration missions, the demonstration of the SP-100 power system is needed by the early 2000 s.

\section{INTRODUCTION}

The President's initiative to return humans to the surface of the moon and then to proceed with human exploration of Mars requires high pertormance propilsion systems for cargo and human transport. Nuclear electric propulsion (NEP) and nuclear thermal propulsion (NTP) have been identified as enabling lechnologies to support the Mars piloted mission. Six panels with members from the U.S. Department of Energy (DOE). National Aeronuutics and Space Administration (NASA), and the U.S. Department of Defense (DOD) were formed to review technology stalus and formulate plans for nuclear propulsion development for a piloted mission to Mars in the 2014 to 2019 timeframe.

Re-establishment of the facilities required for development and to cunduct performance testing will be one of the pacing activities for the NP Program. Thus, a panel was formed to review testing requirements, resulting facility requirements, available facilities, and, then, recommend a facilities strategy for the participating agencies. This panel formed two subpanels to review the facility needs and availability, and funding priority for NEP and NTP, respectively. The activities of the NEP Facilities Pancl are summarized in the remainder of this paper. 


\section{PROCESS}

The Nuelear Electrie Propulsion Faciliten Panel and the Nuclear Electric Propulsion Technology Panel have common members and often met joinlly to ensure the reaponsivenesis of planning. The dovelopment/ demonneration ntrutegy which is advoxiued by the NEP Technology Panel is key to the facilitien plan. NEP systems are comprned of tive mujor subsystems, heat suurce (renctur). energy coriversion. power conditioning. heat rejection, and thrusters (Figure (1). There subsystems are relatively independent and can ho developed und lifettume or performanee demonstruted at the subsystem level. Testing requisemunth for NEP technologlex. components, and subsystems, were provided by the NEP Tecturiologies and the Fuels and Materials Panels (Tuble 1).

TABLE 1. Technology Requirements

\begin{tabular}{|c|c|c|c|c|}
\hline subsystom & $\begin{array}{l}\text { Interplanetary } \\
\text { Precurser } \\
100 \mathrm{kHe} \\
30.50 \mathrm{~kg} / \mathrm{kHe}\end{array}$ & $\begin{array}{l}\text { Lunor/Mars } \\
\text { Cargo } \\
1.5 \mathrm{MHe}, \\
10.20 \mathrm{~kg} / \mathrm{kwe}\end{array}$ & $\begin{array}{l}\text { Macs p1 } \\
500 \cdot 600 \text { Oay } \\
10 \cdot 20 \mathrm{mwe} \\
7 \cdot 10 \mathrm{~kg} / \mathrm{kHe}\end{array}$ & $\begin{array}{l}\text { Oufelk Trip } \\
10.40 \mathrm{mwe} \\
3.7 \mathrm{~kg} / \mathrm{kH}\end{array}$ \\
\hline Reuctor & $\begin{array}{l}\text { Sp. } 100 \text { to Technology } \\
\text { Reediness Level (TRL).5, } \\
1996\end{array}$ & $\begin{array}{l}\text { Sp. } 100 \text { Growth or } \\
\text { Advanced, } 25 \text { Mut, } \\
2000\end{array}$ & Multiple Units & $\begin{array}{l}\text { Advenced } \\
\text { Reector system, } \\
\text { TRL-05, } 2006\end{array}$ \\
\hline $\begin{array}{l}\text { Power } \\
\text { Conversion }\end{array}$ & $\begin{array}{l}\text { thermal Electric, } \\
\text { TRL-5, } 1997\end{array}$ & $\begin{array}{l}\text { Dynamic, TRL·3, } \\
2000\end{array}$ & $\begin{array}{l}\text { Lighe-Nolghe } \\
\text { Oynemic, PRL-5. } \\
2006\end{array}$ & $\begin{array}{l}\text { Upgrade, } \\
\text { TRL-5. } \\
2006\end{array}$ \\
\hline $\begin{array}{l}\text { Radiator. } \\
\text { Heat Rejection }\end{array}$ & $\begin{array}{l}\text { Pumped Loop to TE/Heat } \\
\text { Plpe Radiator, TRL-5. } \\
1997\end{array}$ & $\begin{array}{l}\text { Meat Pipe } \\
\text { Carbon-Carbon, } \\
\text { TRL-5, } 2000\end{array}$ & $\begin{array}{l}\text { Upgrade } \\
\text { TRL-5, } 2006\end{array}$ & $\begin{array}{l}\text { Uporade, TRL-5, } \\
2006\end{array}$ \\
\hline $\begin{array}{l}\text { Power Manage- } \\
\text { ment and } \\
\text { Distribution } \\
\text { (PMAD) }\end{array}$ & $\begin{array}{l}\text { Shielded from Radiation, } \\
\text { Conventional Si } \\
\text { Technology, TRL-5, } 1998\end{array}$ & $\begin{array}{l}\text { Shielded } \\
\text { Conventional. } \\
\text { TRL-5, 2000 }\end{array}$ & $\begin{array}{l}\text { High Tempereture, } \\
\text { Advanced, TRL-5. } \\
2006\end{array}$ & $\begin{array}{l}\text { Upgrade, TRL-S, } \\
2006\end{array}$ \\
\hline Thruster & $\begin{array}{l}\text { Magnetopl asmadynamic } \\
\text { (MPD) or Ion thruster, } \\
\text { TRL-5, 1998, Because of } \\
\text { lifet ime Test }\end{array}$ & $\begin{array}{l}\text { MPO or ton, } \\
\text { TRL-5, } 2000\end{array}$ & $\begin{array}{l}\text { MPD, I in or } \\
\text { Advenced, TRL-3. } \\
2006\end{array}$ & $\begin{array}{l}\text { Upgrade, TRL-S, } \\
2006\end{array}$ \\
\hline
\end{tabular}

One of the major dssumptions/agreements reached by the NEP Technology and Fucilities Panels was that an integrated NEP system test cannot be properly performed on earth. The first test of the entire propulsion system will probably be conducted in space on a demonstration mission. Thus, NEP lends itself to an evolutionary developmental approach where initial precursor missions, such as interplanetary science probes, are conducted witi relatively near-term technologies as dentonstration tests. Later, higher power cargo and piloted missions will use NEP systems comprised of larger scale subsystems or advanced technologies.

The modularity/independence of NEP subsystems greatly reduced the demand on uny individual facility. Most of the NEP subsystems have sculability issues that must be addressed by a rigorous testing program. Thus, all of the recommended facilities ure sized to accommodute those components/subsystems needed for the higher power piloted Mars missions. Subsystem integration tests for the reactor/conversion and thruster/power conditioning will be accommodated in the proposed facilities. 


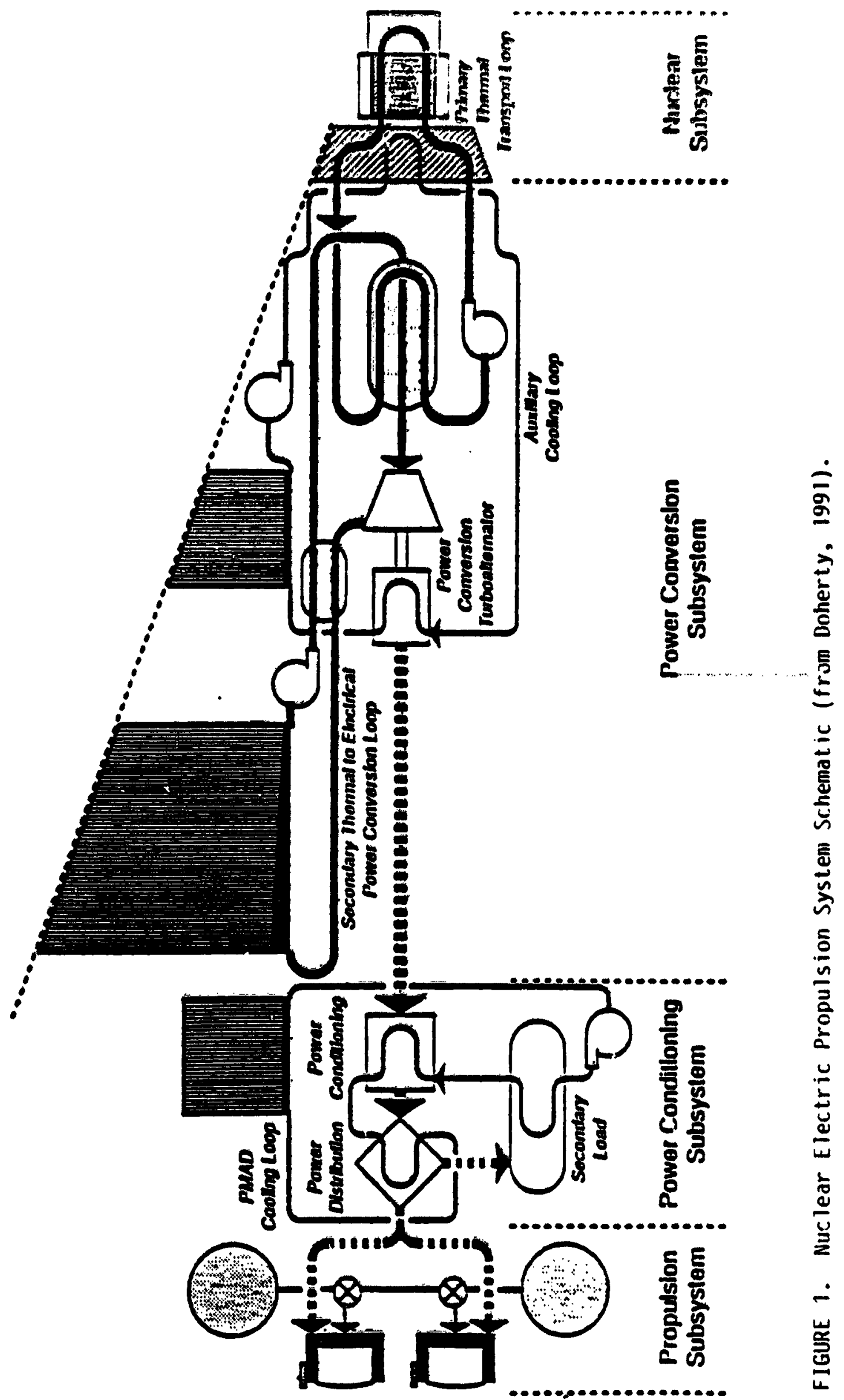




\section{QVERYIEW OF AVALABLE FACILITIES}

The fuelity requirements to met the lesting requirements are provided in Tuble 2.

IABLE 2. Majer facllity Requiraments.

\begin{tabular}{|c|c|c|c|c|}
\hline & Noar Torm & Carge & pileted A & piloted 8 \\
\hline Reacter & $x$ & 50 mint & & $\rightarrow$ \\
\hline Power Convursion & $x$ & $2.5 \mathrm{MHe}=$ & 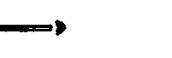 & 3 MWo \\
\hline Heot Rejection & $x$ & $\bullet$ & $\bullet$ & $\cdot$ \\
\hline PMAO & $\cdot$ & $\bullet$ & $\bullet$ & $\bullet$ \\
\hline Phruster & $\begin{array}{l}0.5 \text { mus } \\
\text { Component } \\
\text { and Llfotis } \\
\text { Testing } \\
\text { (2 Facilities) }\end{array}$ & $\begin{array}{l}\text { - } 2 \text { mue for } \\
\text { Upgrede for } \\
\text { Systems Tusts }\end{array}$ & & $\rightarrow$ \\
\hline
\end{tabular}

- No new facillty required, avollable in indusery or laboratorles.

$x$ - Test facillties suppl led by $5 p-100$ progran.

\section{Eacilities to Sunpart Renctor Development}

The S?-100 Flight System Qualification Program is focused on demonstrating technolugy and components for a $100 \mathrm{kWe}$ power system with thermuelectric conversions. Resolution of the issues of SP-100 technolngy scalability and (assuming the technology scules), the applicability of the currently planned SP-100 ground test to the larger, higher powered systems required for 5-40 MWe piloted mission is key to the final facilities plan for reactor development.

In the event an advanced reactor technology is shown to provide significant mission performance benefits, an advanced fuels and materials technology program could be accommodated in existing DOE reactors. If the advanced concept is a liquid-metal-cooled fast reactor, the Fast Flux Test Facility and the Experimental Breeder Reactor-II can accommodate all planned testing. If the concept uses a yas-cooled Brayton cycle, a gas loop could be built for the Advanced Test Reactor.

The decision to conduct a large scale test (either with SP-100 ot advanced technologies) would require an immediate commitment to develop a test facility to meet environmental, satety, and health requirements. The personnel at the SP-100 Test Site at Hanford provided cost and schedule estimates for modification of the facility to accommodate un order of magnitude insreased thermal power (25 MWt). The 8- 10 10-year construction schedule was accepted as typical for all potential reactor test sites. In addition to the Hanford Site, detailed reviews were conducted of the Idaho National Engineering Laboratory (INEL) Contained Test Facility, the Oak Ridge National Laboratory (ORNL) Experimental Gus Cooled Reactor, and the Sandia National Laboratories. Because of the perceived requirement for containment and remote locating. future and more detailed site reviews will focus on INEL, ORNL, and Hanford.

\section{Egcilities to Support Eneroy Conversion Development}

The energy conversion technology used for the piloted Mars mission will most likely be a dynamic system (Brayton, Rankine, or Stirling). NASA and DOE laboratories have been active in energy conversion technology dovelopmert since the 1960s. Historically, Brayton and Stirling conversion has been developed under the direction of NASA centers and Rankine under the direction of DOE center. 
A high lemporature gas loup In suppurt Bribluon at ORNL was revlowed extensively, and NASA-Lewis has an onguing Brayton dovelopment program. Braston lestini! san ho corrolucted hy NASA and ORNL with minor

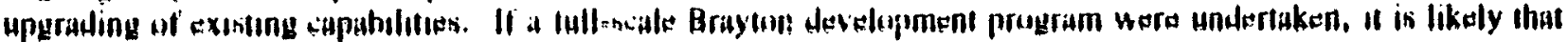

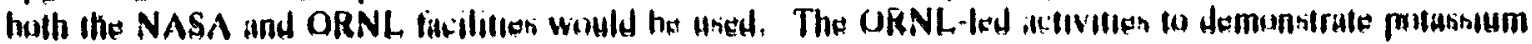
Runkine in the 1960s and early 1970n provided a lectonolung base. Howevis, none of tha facilitien required far development of hoilers. Iurhunes, and rubrysilem tesiting exist today. A nignifieunt program would ha required ta

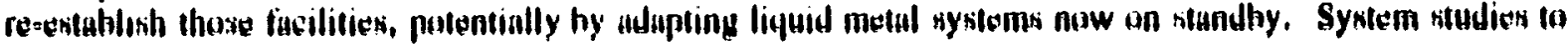

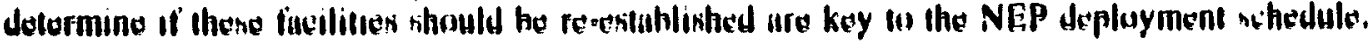

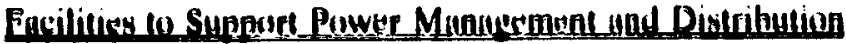

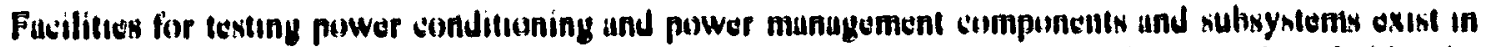

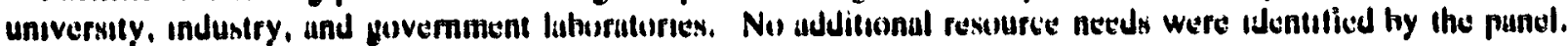

\section{Encilities to Supourt Thruster Develuponent}

lon. magnetoplasmadynamic, and advanced thrusters issues are performance. lifetime, und scalubility. There is a need fur two lest fucilities; une for compounent development lesting and a second for long lerm lifetime and performance lesting. The key parameters for thruster testing facilities is the vacuum chumber size required for the megawalt-class thrusters.

Fucilities at NASA-1.ewis, Lawrence Livermore National Laboratury (LLNL), Oak Ridgo National Luboratory. Amold Engineoring Development Center, Los Alumus Nuttonul Laboratory. und Phillips Luborutories were reviewed for applicubility. All the facilities reviewed will require some modificution to uccommodate the beam dump and achieve appropriale vacuum levels. Because of uvailability considerations, the facilities at NASA-Lew/s, ORNL. und LLNL appear to be the most promusing cundidates (Sovey, 1991).

NASA-Lewis Research Center's Electric Power Laboratory houses two large space simulation chambers, tanks 5 and 6 . Tank 5 is $4.6 \mathrm{~m}$ in diameter and $19 \mathrm{~m}$ long. Sufficient liquid helium or gaseous helium exists for 8-hour tests. Tunk 6 is $7.6 \mathrm{~m}$ in diameter and $22 \mathrm{~m}$ in length. A NASA-finded rehabilitation of the tank is scheduled to be completed in January 1993. The tank will be capable of dissipating 0.35 MWe. The LLNL Magntetic Fusion Tundem Mirror Test Facility (MFTF) is $10.6 \mathrm{~m}$ in diameter and $55 \mathrm{~m}$ long. Large amounts of liquid helium storage capability, us well as $8 \mathrm{~kW}$ and $3 \mathrm{~kW}$ refrigeration/liquefier systems, are available onsite. Large magnets from the original program must be removed to allow use as a thruster test facility. The Large Coil Test Facility (LCTF) at ORNL is a 10.7-m-diameter, 9.1-m-high cylindrical chamber with a removable lid, vacuum capability, and liquid helium wall cooling; however, the helium cryosystems were last operated in 1986.

\section{Eacilities to Sunport Heat Rejection Develonment}

A large number of vacuum shambers of appropriate size exist within industry, particularly aerospace companies. Although some udditional beat rejection sapability may be required, the unticipated costs are within the capability of a typical development program.

\section{RECOMMENDATIONS}

The subpanel recommendations are as follows:

1. Complete the SP-100 ground test and demonstration of thermoelectric conversion before the turn of the century to support flight demonstration and precursor missions;

2. Immediately start modifications to provide a thruster development test facility;

3. Immediately start modifications to provide a thruster lifetime test facility; 


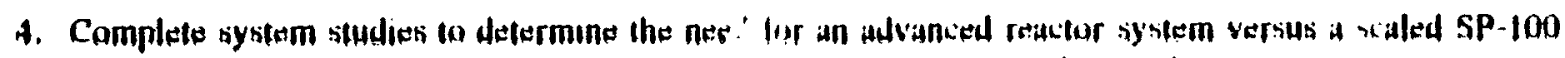

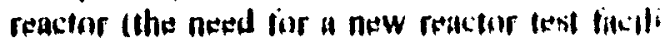
dependent un resiultsi: and

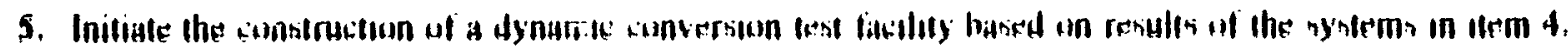

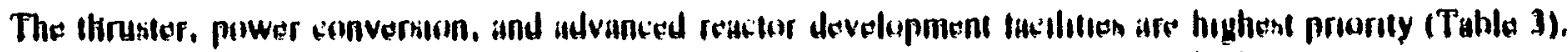

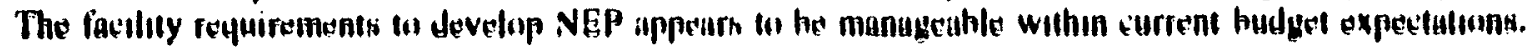

IACLE 3. Ppiopity and Avallabllify of the facllitles to suppopt wrip,

\begin{tabular}{|c|c|c|}
\hline How/Modifleation & $\begin{array}{l}\text { NEP facllley } \\
\text { Punding Ppiority }\end{array}$ & Exigeing foellities \\
\hline \multicolumn{3}{|c|}{ hIONESP } \\
\hline $\begin{array}{l}\text { Thruster Component Devel opment } \\
\text { thruster lifet ime } \\
\text { Oynomic Energy Conversion } \\
\text { Advanced Reactor Ground Posta }\end{array}$ & & 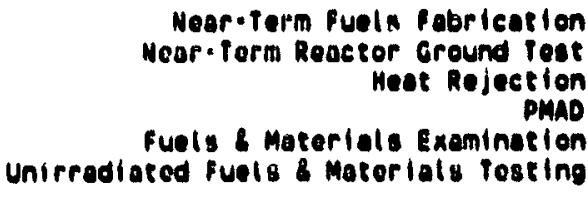 \\
\hline \multicolumn{3}{|c|}{ MEDIUN } \\
\hline $\begin{array}{l}\text { Advanced fuel fabricetion } \\
\text { fuel Etement rest ing loops } \\
\text { Flighe Test Support }\end{array}$ & & $\begin{array}{l}\text { Matertals Irradlation Testing } \\
\text { Safety and off-Normal Operations }\end{array}$ \\
\hline \multicolumn{3}{|c|}{ LOWEST } \\
\hline Advanced thruster (Particles) testing & & $\begin{array}{r}\text { Control Systems } \\
\text { Shielding }\end{array}$ \\
\hline
\end{tabular}

OIf reactor 50 mut is needed, depends upon mission analysis/choices.

\section{Acknowleduments}

The contribution of the following NEP Facilities Panel members Sum Bhuttucharyya (ANL), Jokin Dearien (INEL), Bob Holcumb (ORNL), and Mike Mahaffey (WHC), and the Air Force's Phillips Laboratories and Amold Engineering Developtnent Center provided valuable guidance and technicul balance to the fucilities panel.

\section{Refierences}

Sovey, J. S. et al., (1991), Test Facilities for the Hinh Power Electric Propulsion, AlAA 91-3499. American Institute of Aeronautics and Astronaufics, September 1991.

Doherty, M. P., (1991), Blazing the Trailway: Nuclear Electric Propulsion und Its Technolouy Proseram Plans, AlAA 91-3441. American Institute of Aeronautics and Astrontuutics, September 1991. 
WHC-1402-SA-FP

\section{DISTRIBUTIOA}

Numbor of copios

ONSITE

5

U.S. Dopartmont of Enoray-

Behlond oporations off

C. R. Richins (S)

A6-55

3

Wostinghouso Hanford Comenny

Information Release

Administration (2)

18-07

Document Processing and

Distribution

L8-15

Distr-1 